\title{
The Denier-in-Chief: Climate Change, Science and the Election of Donald J. Trump
}

\section{Kari De Pryck \& François Gemenne}

\section{Law and Critique}

ISSN 0957-8536

Law Critique

DOI 10.1007/s10978-017-9207-6

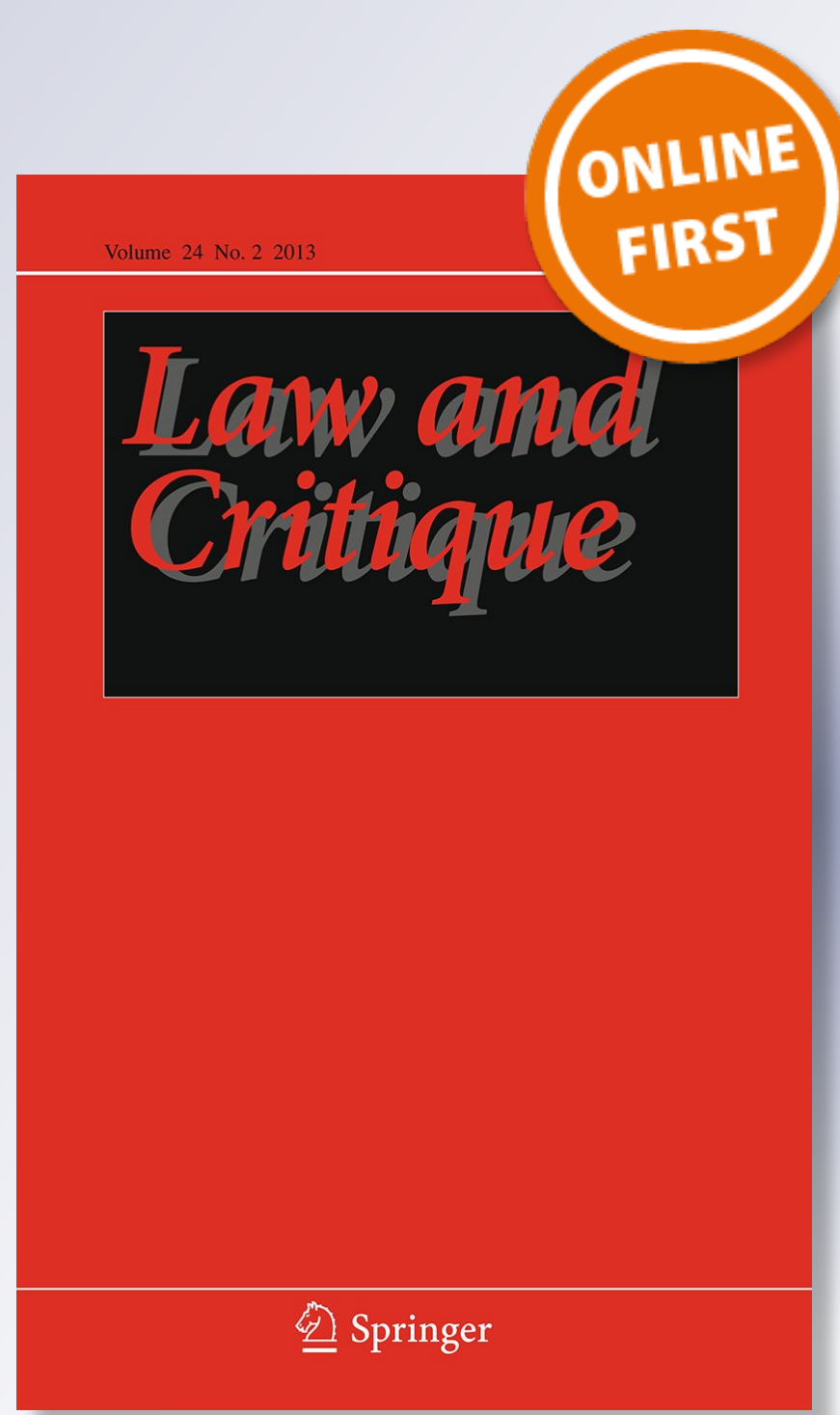

算 Springer 
Your article is protected by copyright and all rights are held exclusively by Springer Science +Business Media Dordrecht. This e-offprint is for personal use only and shall not be selfarchived in electronic repositories. If you wish to self-archive your article, please use the accepted manuscript version for posting on your own website. You may further deposit the accepted manuscript version in any repository, provided it is only made publicly available 12 months after official publication or later and provided acknowledgement is given to the original source of publication and a link is inserted to the published article on Springer's website. The link must be accompanied by the following text: "The final publication is available at link.springer.com". 


\title{
The Denier-in-Chief: Climate Change, Science and the Election of Donald J. Trump
}

\author{
Kari De Pryck ${ }^{1,2}$ - François Gemenne G,4 $^{3,4}$
}

(C) Springer Science+Business Media Dordrecht 2017

\begin{abstract}
The election of Donald J. Trump as the 45th President of the United States reminded us that climate deniers are anything but endangered species. In this short paper, we discuss President Trump's position on climate change in the wider context of climate controversies and denial. In particular, we put it into perspective with other notorious contrarian leaders and their influence on national and international climate politics. Finally, we provide a brief analysis of President Trump discourses on climate change and discuss them in light of reflections about posttruth politics.
\end{abstract}

Keywords Climate controversies · Climate denial $\cdot$ Contrarian leaders · Climate politics · Post-truth

The election of Donald J. Trump as the 45th President of the United States sadly reminded us that climate deniers are anything but endangered species, particularly as country leaders. While many environmental scholars thought (or wished) that his views would soften after his election-during his campaign, Trump went as far as to promise to pull the U.S. out of the Paris Agreement-his first appointments and statements after taking office were no less reassuring as he hardly acknowledged

$\triangle$ Kari De Pryck

kari.depryck@sciencespo.fr

François Gemenne

F.Gemenne@ulg.ac.be; francois.gemenne@sciencespo.fr

1 CERI, Sciences Po, Paris, France

2 Global Studies Institute/Département de Science Politique et Relations Internationales, Université de Genève, Geneva, Switzerland

3 Politics of the Earth, Sciences Po, Paris, France

4 The Hugo Observatory, University of Liège, Liège, Belgium 
'some connectivity' between human activity and climate change and confirmed that he will be '[...] looking at it very closely [and] [...] [wi]ll let you know' (New York Times 2016). The new President is, however, not an exception. In this short piece, we situate his views in the context of climate controversies and in the network of powerful actors that, for decades, have fueled climate denial, particularly in the U.S. Then, we draw attention to the role of contrarian politicians at top level positions in stalling the national and international climate debates.

\section{Two Decades of Climate-Denial}

Far from being a recent phenomenon, the rejection of the scientific consensus on climate change emerged more or less at the same time as environmental problems were put on the international agenda. McCright and Dunlap (2001) were among the first to study the appearance in the early 1990s of a 'countermovement' supported by conservative think tanks with the explicit aim to counter the endorsement of the Kyoto Protocol by the U.S. (a rather successful endeavour as the country never ratified it). In the following decade, a multitude of studies were produced to describe these groups and the strategies they used to influence public views and decisionmaking.

Various terms have been used to describe the individuals or groups that question the scientific consensus about anthropogenic climate change. Some scholars have argued that this attitude should be distinguished from 'scepticism' that is an inherent and 'healthy' characteristic of science (Mann 2012, p. 26; Dunlap 2013) and recommended 'deniers' or 'contrarians' for those who reject all evidence of anthropogenic climate change. It has also been argued that public views are not sceptical, but rather ambivalent or simply unconcerned (Poortinga et al. 2011). Scholars have also distinguished several types of deniers: those who reject all evidence of global warming; those who believe human activities are not causing global warming; those who accept the reality of global warming but claim that its impacts will be minor, if not beneficial; and those who question the economic and political measures proposed to deal with it (McCright and Dunlap 2000; Rahmstorf 2004; Hoffman 2011). Often, deniers hold a mix of these beliefs.

Researchers have exposed the great diversity of protagonists behind the disinformation campaigns aimed at spreading doubts, 'keeping the controversy alive' and 'manufactur[ing] uncertainty' (Oreskes and Conway 2010; Hoggan 2009; Powell 2011; Dunlap 2013). They identified a loose coalition gathering the fossil fuel industry (e.g. Koch Industries and ExxonMobil), a number of conservative foundations and think-tanks (e.g. the Heartland and George C. Marshall Institutes) and traced their financial support to 'a range of front groups and Astroturf operations' (Dunlap 2013, p. 692). These groups also benefited from the support of conservative media and politicians, as their arguments resonated well with the antiregulatory stance of the U.S. Republican Party and later of the Tea Party. In challenging mainstream climate science, these groups could also count on the support of a few recognized scientists (Oreskes and Conway 2010). These scientists (e.g. Fred Seitz and Fred Singer) were physicists having served for decades in high 
levels of science administration, that felt at odds with growing environmental concerns and the introduction of new modes of knowledge production, in particular climate models (Lahsen 2008, 2013).

This 'denial machine' has its roots in the activities that the Tobacco Industry carried out in the 1950 s to counter the mounting evidence of the link between cigarettes and lung cancer (Oreskes and Conway 2010). Likewise, the objective of climate deniers has been to challenge the scientific consensus on human-induced climate change and propagate the idea that the science is not settled. This was in turn used to argue against the necessity to take actions that could threaten the economy (and the interests of high-emission industries). Their strategies ranged from editing reports, to writing editorials and commentaries in conservative media and blogs, to appearing on television, and more rarely, to publishing in peerreviewed articles (Anderegg et al. 2010). Their arguments could be found in online publications and were relayed through the press, radio, and television (Oreskes and Conway 2008). Many media outlets failed to represent the disjuncture between the scientific consensus and the sceptical claims (Boykoff and Boykoff 2004; Painter 2011).

The focus on science explains why the privileged target of the denier groups has long been the Intergovernmental Panel on Climate Change (IPCC), the UN body responsible for assessing scientific knowledge on climate change since 1988. In 1995, one of its leading scientists, Ben Sander, was accused of 'corruption of the peer-review process' regarding a sentence of the Summary for Policymakers (SPM) of the IPCC Second Assessment Report that stipulated that 'the balance of evidence suggests that there is a discernible human influence on global climate' (Edwards and Schneider 1997, p. 3). In 2001, the organization came under fire again for displaying in its Third Assessment Report the famous 'hockey stick graph' by Mann et al. (1999), which would become an icon in the climate change debate (Mann 2012). Finally, the biggest wave of criticism came in 2009 when errors were found in the IPCC Fourth Assessment Report, only a few weeks after the breaking of the 'Climategate' controversy (which supposedly exposed the 'impure' and 'biased' nature of climate science through the diffusion of emails stolen from the Climatic Research Unit at the University of East Anglia).

The view of science and politics that underpins climate denial is that of the socalled 'linear model' according to which scientific knowledge, produced in an untainted and non-political manner, is transmitted to policymakers and supports their informed decisions (Pielke 2007). While the linear model is simplistic, it still remains anchored in public perceptions and offers a weak spot for sceptical attacks (Sarewitz 2010). By emphasizing the situated and socially embedded nature of climate science, contrarians aimed to raise doubts about scientific consensus and thereby undermine the justification of climate policies.

Likewise, as it provides a rather advantageous way of dividing responsibilities between scientists and policymakers, the linear model is not challenged by policymakers. According to this model, the former are responsible for delivering facts and the latter for making value judgments based on those facts (Pielke 2007). However, in the face of the increasingly complex and uncertain nature of transnational environmental problems ('super wicked' problems according to Levin 
et al. 2012), that arrangement between science and politics has become less and less tenable. According to Latour (2012), the scientists under attack-but also those that supported them-have been hoisted by their own petard as they have always insisted on the virtue of scepticism and on the need to keep science isolated from politics.

\section{Contrarian Leaders}

The stances of President Trump on many issues are often so outrageous that one could think they are isolated on the international stage. Yet this is far from being the case. First, Trump is not the first sceptical politician to hold the presidency or government of a country. Former U.S. President George W. Bush (2001-2009) has already been criticized for undermining climate science and refusing to ratify the Kyoto Protocol (Dunlap and McCright 2008). More recently, former Australian Prime Minister (2013-2015), Tony Abbott, also emerged as a convinced climate contrarian and stated in his book Battlelines that 'whether humans have had a significant impact on the climate as a whole is much less clear. Climate change is a relatively new political issue, but it's been happening since the earth's beginning' (Abbott 2009, p. 169). Abbott came forward as a fierce opponent of climate policies that would, in his view, hurt the Australian economy. Canada's former Prime Minister, Stephen Harper (2006-2015), shared a similar view. During his tenure, he officially maintained that climate change is a major threat for future generations, but his country pulled out of the Kyoto Protocol claiming that it did 'not represent the path forward for a global solution to climate change [but an] impediment', as it did not include major emitters like China and the U.S. (in the words of Peter Kent, former Minister of the Environment-The Guardian 2011). Another lesser-known contrarian is former Czech President, Vaclav Klaus (2003-2013), who compared global warming to communism (Klaus 2010). Klaus was particularly close to American contrarian lobbies and attended several conferences organized by the conservative think-tank Heartland Institute. Former French President Nicolas Sarkozy also seemed to ride the wave of denial recently, suggesting, during the primary elections, that climate change was not primarily caused by human activities (Dagorn 2016). These politicians share similar views about climate science and they all have an acute sense that climate policies would damage their national economies. Like the majority of politicians in the Western world, they also have in common that they are all conservative white men (McCright and Dunlap 2011).

The experience of the U.S. under Bush, of Canada under Harper, and of Australia under Abbott showed that these politicians have used various strategies to divert public and political attention away from climate change policies. This can be done by appointing climate deniers at the head of scientific agencies, abolishing advisory panels and scientific programmes, cutting funding to environment portfolios as well as reorienting research towards more industry-relevant research (Hoag 2012). More troubling are the growing accusations of censorship by federal scientists during Harper's mandate who needed approval to communicate their research to media, particularly for issues related to climate change and the environment (Ogden 2016). 
Some commentators even spoke of 'Canada's war on science' (Turner 2014). Depending on the responsibilities allowed by the constitution of their country and the contextual distribution of power, these leaders may have more or less influence in stalling the debate. At a minimum, their position can allow them a 'bully pulpit' to expose their views and influence the debate. The symbolic power of these leaders can help to mainstream climate contrarian opinions.

Donald J. Trump is walking in the steps of his predecessors. He appointed at the head of the Environmental Protection Agency (EPA), the federal agency responsible for the protection of human health and the environment, Scott Pruitt, known for having led several lawsuits against the EPA. Pruitt recently claimed that human activity is not the primary contributor to global warming (DiChristopher 2017). Trump also nominated Rex Tillerson, former CEO of ExxonMobil, as Secretary of State. A bill was introduced a week after Trump's inauguration to cut financial contributions to the IPCC, the UNFCCC (United Nations Framework-Convention on Climate Change), and the Green Climate Fund-the former had already been subjected to major cuts in 2011. He also recently signed an order to undo the Clean Power Plan supported by his predecessor, Barack Obama, which aimed at cutting greenhouse gas emissions from power plants. President Trump has made it clear that there are much more important environmental issues than climate change such as clean water, diseases, and food production, and that the environment comes after the competitiveness of the country (New York Times 2016; see McGee 2017 for a discussion of Donald J. Trump's political ecology).

\section{Post-truth and Trump}

If President Trump's views on climate change are not different from contrarian arguments, the way in which he voices his opinions is distinctive. To explore his position, we relied on the Trump Twitter Archive ${ }^{1}$ and the New York Times interview transcript (2016). To some extent, climate sceptics were 'playing the game of science' in the sense that they advanced their claims while abiding to the forms of scientific debate (i.e. making the effort to disguise pseudo-evidence as 'scientific' facts). This is rarely so in President Trump's case and questions can be raised about the revival of climate-denial in a 'post-truth' context. In that context, 'facts no longer provide a compelling epistemic base for presenting and resolving disputes. Instead, a partisan base provides the discursive and institutional support for a parallel universe of alt-news, alt-facts, and alt-reality' (Lynch 2017). Accordingly, scientific claims on climate can be dismissed or weakened by reference to personal beliefs: what President Trump calls 'keeping an open-mind' (New York Times 2016). According to him, cold and snowy days are enough evidence to dismiss global warming. When asked about whether he believed in climate change, Trump (New York Times 2016) referred to his uncle (an MIT engineer) saying that he 'had a feeling on [climate change]. It's a very complex subject. I'm not sure anybody is ever going to really know' (note the reference to

\footnotetext{
${ }^{1}$ http://www.trumptwitterarchive.com/.
} 
feelings instead of scientific evidence). Above all, Trump seems to base his opinion on climate change on whether it is economically viable or not:

I think right now ... well, I think there is some connectivity [between climate change and human activities]. [...] It depends on how much. It also depends on how much it's going to cost our companies. You have to understand, our companies are noncompetitive right now. (New York Times 2016, emphasis added).

Trump rarely provides sources for his positions on Twitter and, when he does, he refers to media and blogs (e.g. Wall Street Journal and wattsupwiththat.com both have proved sympathetic to contrarian voices). Trump's arguments are a mix of personal beliefs, lies ('alternative facts' in his view) and conspiracy theories. He regularly suggests that scientists purposely adopted the term climate change instead of global warning because 'it did not work anymore'. He also mentioned the Climategate emails (New York Times 2016) and tweeted in 2012 that 'global warming is based on faulty science and manipulated data which is proven by the emails that were leaked'. He even claimed that climate change was a Chinese conspiracy, a concept 'created by and for the Chinese in order to make U.S. manufacturing non-competitive'.

It is too early to say whether Trump will be able to dismantle the engagements undertaken by the international community and the U.S. in recent years (particularly in the 2015 Paris Agreement). At COP22 $2^{2}$ in Marrakech, U.S. diplomats did their very best to convince their colleagues that 'nothing could stop the momentum', and that the market and economic forces had already started their transformation towards sustainability. Overall, diplomats-and not only American diplomatsdownplayed the importance of the U.S. presidential election for the future of the international cooperation on the fight against climate change, as if politics did not matter anymore. In our opinion, that is a foolish view. And whether the U.S. remains a party to the Paris Agreement or not the damage is already done. First, the mere fact that a candidate openly sceptical on climate science can get elected to the very top office of a major emitter of greenhouse gas shows that climate change is not yet a priority for the electorate. Second, the Paris Agreement is a symbolic, political declaration: an important one, but with no binding commitments. The real test will lie in the capacity of all countries to upgrade their commitments in the years to come. And even if the U.S. remains party to the agreement, it seems clear that the country will not commit to drastic emissions' reductions in the future-yet this is absolutely needed, from the U.S. and many other countries. And the views of President Trump, alas, are not isolated on the international scene: without going as far as questioning the reality of climate change, many governments are very reluctant to implement meaningful climate action. Trump's election will not encourage a different approach. As the principle of universality is the cornerstone of the Paris Agreement, it seems difficult to imagine that countries like Russia, Japan

\footnotetext{
2 The 22nd Conference of the Parties (COP 22) to the UN Framework Convention on Climate Change (UNFCCC).
} 
or Australia would upgrade their commitments if the U.S. does not. And this alone could ruin the ambition of the Paris Agreement.

This shows that consequences of having contrarian politicians elected at top level positions loom large. The fact that the President of the United States, and other world leaders, are rejecting climate science is not anecdotal or trivial. Yet to this day, very few studies exist on the impact of contrarian leaders on international and domestic climate policies. Standing up against an administration, even in an academic way, can be costly, as governments can sometimes have significant influence on research funding and scientific careers. In the coming years, it will be crucial to investigate if and how the system of checks-and-balances defuses Trump's denial—as many observers hoped at COP22 in Marrakech.

\section{References}

Abbott, Tony. 2009. Battlelines. Melbourne: Melbourne Univ. Publishing.

Anderegg, W.R., J.W. Prall, J. Harold, and S.H. Schneider. 2010. Expert credibility in climate change. Proceedings of the National Academy of Sciences 107 (27): 12107-12109.

Boykoff, Maxwell T., and Jules M. Boykoff. 2004. Balance as bias: Global warming and the US prestige press. Global Environmental Change 14 (2): 125-136.

Dagorn, Gary. 2016. Les volte-face de Nicolas Sarkozy sur le changement climatique. Le Monde. http:// www.lemonde.fr/les-decodeurs/article/2016/09/15/les-volte-face-de-nicolas-sarkozy-sur-lechangement-climatique_4998385_4355770.html\#S48VEgAm31TfyCPX.99. Accessed 10 March 2017.

DiChristopher, Tom. 2017. Scott Pruitt's latest climate change denial sparks backlash from scientists, environmentalists. CNBC. http://www.cnbc.com/2017/03/09/scott-pruitts-latest-climate-changedenial-sparks-backlash.html. Accessed 10 March 2017.

Dunlap, Riley E. 2013. Climate change skepticism and denial: An introduction. American Behavioral Scientist 57(6): 691-698. https://doi.org/10.1177/0002764213477097. Accessed 10 March. 2017.

Dunlap, Riley E., and Aaron M. McCright. 2008. A widening gap: Republican and Democratic views on climate change. Environment: Science and Policy for Sustainable Development 50 (5): 26-35.

Edwards, P.N., and S.H. Schneider. 1997. The 1995 IPCC report: Broad consensus or 'scientific cleansing'. Ecofable/Ecoscience 1 (1): 3-9.

Hoffman, Andrew J. 2011. Talking past each other? Cultural framing of skeptical and convinced logics in the climate change debate. Organization \& Environment 24 (1): 3-33.

Hoag, H. 2012. Canadian budget hits basic science. Innovation wins over basic research and the environment. Nature. http://www.nature.com/news/canadian-budget-hits-basic-science-1.10366. Accessed 10 March 2017.

Hoggan, James, and Richard Littlemore. 2009. Climate cover-up: The crusade to deny global warming. Vancouver: Greystone Books Ltd.

Klaus, Vaclav. 2010. The Climate change doctrine is part of environmentalism, not of science. https:// www.klaus.cz/clanky/2694. Accessed 11 March 2017.

Lahsen, Myanna. 2008. Experiences of modernity in the greenhouse. Global Environmental Change 18: 204-219.

Lahsen, Myanna. 2013. Anatomy of dissent: A cultural analysis of climate skepticism. American Behavioral Scientist 57 (6): 732-753.

Latour, Bruno. 2012. Que la bataille se livre au moins à armes égales. In Controverses climatiques, sciences et politique, ed. E. Zaccai, F. Gemenne, and J.M. Decroly. Paris: Presses de Sciences Po.

Levin, Kelly, B. Cashore, S. Bernstein, and G. Auld. 2012. Overcoming the tragedy of super wicked problems: Constraining our future selves to ameliorate global climate change. Policy Sciences 45 (2): $123-152$. 
Lynch, Michael. 2017. Post-truth, alt-facts, and asymmetric controversies (Part II). http://first100days. stsprogram.org/2017/02/20/post-truth-alt-facts-and-asymmetric-controversies-part-ii/. Accessed 11 March 2017.

Mann, Michael E., Raymond S. Bradley, and Malcolm K. Hughes. 1999. Northern hemisphere temperatures during the past millennium: Inferences, uncertainties, and limitations. Geophysical Research Letters 26 (6): 759-762.

Mann, Michael E. 2012. The hockey stick and the climate wars. New York: Columbia University Press.

McCright, Aaron M., and Riley E. Dunlap. 2000. Challenging global warming as a social problem: An analysis of the conservative movement's counter-claims. Social Problems 47 (4): 499-522.

McCright, Aaron M., and Riley E. Dunlap. 2011. Cool dudes: The denial of climate change among conservative white males in the United States. Global Environmental Change 21 (4): 1163-1172.

McGee, Kyle. 2017. Heathen Earth. Trumpism and political ecology. Punctum books.

New York Times. 2016. Donald Trump's New York Times interview: Full transcript https://www.nytimes. com/2016/11/23/us/politics/trump-new-york-times-interview-transcript.html?_r=1. Accessed 10 March 2017.

Ogden, Lesley E. 2016. Nine years of censorship. Nature. http://www.nature.com/news/nine-years-ofcensorship-1.19842. Accessed 10 March 2017.

Oreskes, Naomi, and Erik M. Conway. 2010. Merchants of doubt. New York: Bloomsbury Publishing.

Oreskes, Naomi, and Erik M. Conway. 2008. Challenging knowledge: How climate science became a victim of the cold war. In Agnotology. The making and unmaking of ignorance, ed. R. Proctor, and L. Schiebinger. Stanford: Stanford University Press.

Painter, James. 2011. Poles apart. Oxford: Reuters Institute for the Study of Journalism.

Pielke Jr, Roger A. 2007. The honest broker: Making sense of science in policy and politics. Cambridge: Cambridge University Press.

Poortinga, W., A. Spence, L. Whitmarsh, S. Capstick, and N.F. Pidgeon. 2011. Uncertain climate: An investigation into public scepticism about anthropogenic climate change. Global Environmental Change 21 (3): 1015-1024.

Powell, James Lawrence. 2011. The inquisition of climate science. New York, NY: Columbia University Press.

Rahmstorf, Stefan. 2004. The climate sceptics. In The State of Science. Weather catastrophes and climate change: Is there still hope for us. ed. Munich Re. Munich: PG Verlag. The state of science. http:// www.pik-potsdam.de/ stefan/Publications/Other/rahmstorf_climate_sceptics_2004.pdf. Accessed 13 March 2017.

Sarewitz, Daniel. 2010. Curing climate backlash. Nature 464 (7285): 28.

The Guardian. 2011. Canada pulls out of Kyoto protocol. https://www.theguardian.com/environment/ 2011/dec/13/canada-pulls-out-kyoto-protocol. Accessed 10 March 2017.

Turner, Chris. 2014. The war on science: Muzzled scientists and wilful blindness in Stephen Harper's Canada. Vancouver: Greystone Books Ltd. 